\title{
Journal of Cancer Science \& Therapy
}

\section{RNA Expression of Cytochrome P450 and its Clinical Impact in Breast Cancer Patients}

\author{
Kanakaiah Thota ${ }^{1^{*}}$, Prasad $\mathrm{K}^{2}$ and Mandava V Basaveswara $\mathrm{Rao}^{3}$ \\ ${ }^{1}$ Department of Pharmacology, Krishna University, Patha Pet, College Road, Nuzvid, Rajupeta, Machilipatnam, Andhra Pradesh, India \\ ${ }^{2}$ Department of Pharmacology, Shri Vishnu College of Pharmacy, Bhimavaram, Andhra Pradesh, India \\ ${ }^{3}$ Dr. Mrar PG Centre, Krishna University, Patha Pet, College Road, Nuzvid, Rajupeta, Machilipatnam, Andhra Pradesh, India
}

"Corresponding author: Kanakaiah Thota, M. Pharmacy, Department of Pharmacology, Krishna University, Patha Pet, College Road, Nuzvid, Rajupeta, Machilipatnam, Andhra Pradesh, India, Tel: 91 9704767511; E-mail: kanakaiahthota.pharma@gmail.com

Rec date: July 21, 2018; Acc date: October 01, 2018; Pub date: October 03, 2018

Copyright: ( 2018 Thota K, et al. This is an open-access article distributed under the terms of the creative common's attribution license, which permits unrestricted use, distribution, and reproduction in any medium, provided the original author and source are credited.

\#All authors contributed equally to this work.

\begin{abstract}
Objectives: The expression pattern of cytochrome P450 genes (CYPs) affected by tumorigenesis may have an important role in the progression of cancer and in the metabolism of anticancer drugs. The aim of the present study was to determine the mRNA expression pattern of two cytochrome P450 genes (CYP3A4, and CYP3A5) in breast cancer patients.

Methods: Tumor samples were collected from 38 patients recently diagnosed with breast cancer along with corresponding non-malignant tissues. Quantitative polymerase chain reaction (qPCR) was used to quantify the levels of gene expression in all the samples. The association between CYPs expression and clinico-pathological parameters was also analyzed.
\end{abstract}

Results: In the present study, our results showed that CYP3A5 gene expression was not significantly associated with breast cancer $(p=0.14)$. Significant differences in CYP3A4 mRNA expression were observed between tumor tissue and the corresponding normal tissue $(p<0.003)$. There was no statistical difference between CYP3A4 and CYP3A5 expression and clinical and pathological features.

Conclusion: CYP3A4 expression has a potential role as a breast cancer prognosis marker. We conclude that increased expression levels of the examined CYP $3 A 4$ may promote breast cancer progression and also may associate with resistance to drug treatment by inactivation of anticancer drugs. Moreover, one potential therapeutic approach may be to block CYP3A4 function.

Keywords: Breast cancer; Cytochrome P450; CYP2D6; CYP3A4; CYP3A5; Gene expression; Drug gene interactions

\section{Introduction}

Breast cancer is the most common cancer in the female population responsible for $15 \%$ of cancer-related deaths [1]. Cytochrome P450 (CYP450) is a super family of hemoprotein that can be found in all species and are essential for survival. CYP450 contains monooxygenases and are involved in the metabolism of a wide range of exogenous and endogenous compounds including drugs, toxins and carcinogens [2]. The gene expression of CYP450s in different organs alter pharmacological outcomes of medication [3]. Interindividual variability in the expression of cytochrome p450 may contribute to interindividual differences in drug efficacy and adverse reactions. More than 2 million adverse drug reaction cases were reported annually in the United States, because only $25-60 \%$ patients are responding to specific medication. Drugs are usually approved based on safety and efficacy data in a limited number of patients that are thought to represent the entire population. However, individuals in a population show differences in drug sensitivity, efficacy, toxicity, and dosing [4]. Anticancer agents such as cyclophosphamides, anthracyclines, taxanes, tamoxifen and irinotecan are metabolized by $C Y P 450$ s. The efficacy and toxicity of these agents are greatly influenced by $C Y P 450$ genetic polymorphisms and differential enzymatic activities. The expression of tumor specific proteins in mammary glands may play a critical role in the development of breast cancer as well as in the success of chemotherapy treatment. To date, very few critical markers have been validated for the prediction of drug efficiency in breast cancer. Thus, the aim of the present study was to determine the mRNA expression pattern of three representative CYPs (CYP3A4, and CYP3A5) in paired tumor and normal tissue of breast cancer patients [5].

\section{Materials and Methods}

\section{Tissue samples, ethics statement and consent form}

Fifty tumor and corresponding non-tumor tissues from adjacent regions were obtained from patients diagnosed with breast cancer from MNJ Institute of Oncology and Regional Cancer Centre, Hyderabad, between 2016 and 2017. Tumor and non-tumor tissue samples had been verified as tumor or non-tumor by histopathological evaluation. The study protocol was approved by the Institutional Ethics Committee and written informed consent was obtained from all patients. A group 
of candidate genes were chosen, and the expression was analyzed by qRT-PCR.

\section{RNA extraction}

Total RNA was isolated using Isolation Kit (Qiagen) its integrity was verified by $1.5 \%$ agarose gel plus ethidium bromide and the ratio of optical density (OD) at $260 \mathrm{~nm}$ and $280 \mathrm{~nm}$ was also measured. RNA was quantified using a NanoDropND-1000 Spectrophotometer (Thermo Scientific) and single-stranded cDNA was synthesized from 300 ng of RNA in each sample.

\section{Reverse transcription}

Reverse transcription was performed in a personal Master Cycler (Bio-Rad CFX 96), using $1 \mu \mathrm{g}$ of total RNA in the presence of Random Hexamer $(50 \mathrm{ng} / \mu \mathrm{l})$ and reverse transcriptase $(50 \mathrm{U} / \mu \mathrm{l})$ in a total volume of $20 \mu$ l, including: $10 \times$ TaqMan RT buffer, $\mathrm{MgCl}_{2}$ solution (25 $\mathrm{mM})$, dNTPs mixture $(10 \mathrm{mM})$, an RNAse inhibitor $(20 \mathrm{U} / \mu \mathrm{l})$ and nuclease-free water. The reaction mixture was incubated for 10 minutes at $25^{\circ} \mathrm{C}, 60$ minutes at $42^{\circ} \mathrm{C}$, heated for 5 minutes to $95^{\circ} \mathrm{C}$ and then at $4^{\circ} \mathrm{C}$ for a minimum of 2 minutes. The resulting cDNA was stored at $-20^{\circ} \mathrm{C}$ until further use.

\section{SYBR-Green quantitative reverse transcription-PCR (qRT- PCR)}

The CYP2D6, CYP3A4, and CYP3A5 levels were quantified by quantitative reverse transcription-PCR (qRT-PCR) using SYBR-Green. Quantification of the expression of miR- CYP2D6,CYP3A4, and CYP3A5 genes was performed using Bio-Rad CFX96. The relative quantification method was used, where we compared the gene expression in each patient with the gene expression in the control group. In assessing the relative gene expression, quantitative real time polymerase chain reaction (qRT-PCR) was performed with $1 \mu \mathrm{l}$ of cDNA, $12.5 \mu$ l SYBR Green, and with specific primers (Table 1) were synthesized at Bioserve Biotechnologies Ltd (Hyderabad, India).

\begin{tabular}{|l|l|l|l|}
\hline \multirow{2}{*}{ Gene } & Oligonucleotide & Sequence & $\begin{array}{l}\text { PCR } \\
\text { product } \\
\text { size }\end{array}$ \\
\hline \multirow{2}{*}{ CYP3A4 } & 5-Primer & AACGGCACCTCCATGTG & \multirow{2}{*}{$186 \mathrm{bp}$} \\
\cline { 2 - 3 } & 3-Primer & GCGTTGTGATCTCCTTCTGA & \\
\hline \multirow{2}{*}{ CYP3A5 } & 5-Primer & GCCAAGCCCATAACTCAG & \multirow{2}{*}{$152 \mathrm{bp}$} \\
\cline { 2 - 3 } & 3-Primer & AATCTCAGGTTCACAGGTTAAG & \\
\hline \multirow{2}{*}{ GAPDH } & 5-Primer & AATCCCATCACCATCTTCCAG & \multirow{2}{*}{$121 \mathrm{bp}$} \\
\cline { 2 - 3 } & 3-Primer & AAATGAGCCCCAGCCTTC & \\
\hline
\end{tabular}

Table 1: Oligonucleotide primer sequence used for RT-PCR.

The program used was: $5 \mathrm{~min}$ of initial denaturation and enzyme activation at $95 \mathrm{C}$, followed by 35 cycles composed of $30 \mathrm{~s}$ at $95 \mathrm{C}, 30 \mathrm{~s}$ at $60 \mathrm{C}$ for annealing and $40 \mathrm{~s}$ at $72 \mathrm{C}$ for elongation. Amplification and melting curve analysis were carried out to verify the specific product according to its specific melting temperature (Tm). Each reaction was performed in triplicate. Gene expression was defined based on the threshold cycle $(\mathrm{Ct})$, and relative expression levels were calculated as 2 -[(Ct of RNA)-(Ct of reference gene)] after normalization with reference to expression of U6. The results were analyzed by the melting curve analysis software. Gene expression values were expressed as Ct, $\mathrm{Ct}$ being the point at which the fluorescence rises significantly above baseline or background fluorescence and comparing the $\mathrm{Ct}$ of the genes in tumors with the $\mathrm{Ct}$ of the genes in controls.

\section{Statistical analysis}

Statistical analyses for RT-PCR results were performed on $\triangle \mathrm{CT}$ data. $p$-Values $<0.05$ were considered statistically significant.

\section{Results}

\section{Clinical and pathological characteristics}

We obtained data on 38 female patients with breast cancer. Thirtyeight breast biopsy samples were compared with normal pooled breast tissue. The clinicopathological data for the patients recruited in this study are provided in Table 2 .

\begin{tabular}{|c|c|}
\hline Clinical Characteristics & $\mathrm{N}=38$ \\
\hline \multicolumn{2}{|l|}{ Menopausal Status } \\
\hline Premenopausal & $24(63 \%)$ \\
\hline Postmenopausal & $14(37 \%)$ \\
\hline \multicolumn{2}{|l|}{ Tumor Size } \\
\hline$>2$ & $24(63 \%)$ \\
\hline$<2$ & $14(37 \%)$ \\
\hline \multicolumn{2}{|l|}{ Tumor Grade } \\
\hline Grade II & $28(74 \%)$ \\
\hline Grade III & $10(26 \%)$ \\
\hline \multicolumn{2}{|l|}{ Lymph Nodes } \\
\hline No Nodes & $20(53 \%)$ \\
\hline $1-5$ & $14(37 \%)$ \\
\hline Above 5 & $4(10 \%)$ \\
\hline \multicolumn{2}{|l|}{ Hormonal Status } \\
\hline ER/PR Positive & $14(37 \%)$ \\
\hline ER/PR Negative & $24(63 \%)$ \\
\hline Her-2 Positive & $14(37 \%)$ \\
\hline Her-2 Negative & $24(63 \%)$ \\
\hline Ki-67 Positive & $28(74 \%)$ \\
\hline Ki-67 Negative & $10(26 \%)$ \\
\hline
\end{tabular}

Table 2: Clinical and pathological characteristics of breast cancer patients.

The mean age of the breast cancer breast cancer patients was 47 years (Ranging from 29-73). Most of the breast cancer patients of invasive ductal carcinomas were grade II $(74 \%)$ and grade III $(26 \%)$. The percentage of ER/PR negative tumors (63\%) was high when 
compared to ER/PR positive tumors (37\%). Her-2 negative tumors were found high frequency (63\%) than Her-2 positive tumors (37\%). $74 \%$ (28 of 38 ) cases were Ki-67 positive and $26 \%$ (10 of 38) were Ki-67 negative.

\section{Frequency of expression of CYP3A4}

In the group of 38 pairs of breast cancer tumor tissue and the corresponding normal tissue obtained from the same patient, in most cases expression of the CYP3A4 gene was higher in tumor than in the control tissue. Significant differences in CYP3A4 mRNA expression were observed between tumor tissue and the corresponding normal tissue $(\mathrm{p}<0.003)$. The mean relative expression for $C Y P 3 A 4$ was significantly, two-fold higher in breast tumor tissues (Table 3 ).

\begin{tabular}{|l|l|l|l|l|}
\hline \multicolumn{2}{|l|}{ Analyses } & Tumor & Normal & p-Value \\
\hline \multirow{2}{*}{ CYP3A4 } & Altered Expression & $16(42 \%)$ & $10(26 \%)$ & \\
\cline { 2 - 4 } & Normal Expression & $22(58 \%)$ & $28(74 \%)$ & 0.14 \\
\hline \multirow{2}{*}{ CYP3A5 } & Altered Expression & $20(52 \%)$ & $0(0 \%)$ & \\
\cline { 2 - 4 } & Normal Expression & $18(48 \%)$ & $38(100 \%)$ & 0.003 \\
\hline
\end{tabular}

Table 3: RT-PCR analyses of CYP3A4 and CYP3A5 mRNA expression in breast cancer patients.

\section{Frequency of expression of CYP3A5}

In 16 of the 38 (42\%), CYP23A5 was over expressed in the breast cancer tissue when compared with its expression in corresponding normal tissue. Normal expression was demonstrated in 58\% of tumor tissues. In corresponding normal tissue expression was detected in 10 of 38 (26\%). Therefore, CYP3A5 gene expression was not significantly associated with breast cancer $(\mathrm{p}=0.14)$.

\section{CYP3A4 and CYP3A5 over expression and their correlation with clinic pathologic factors}

In this study, several key clinicopathological factors were collected to access the correlation with the expression level of $C Y P 3 A 4$ or CYP3A5. Detailed clinicopathological factors (including age, gender, and lymph node metastasis) are summarized in Table 4 . The level of CYP3A4 and CYP3A5 mRNA expression was found to be high in premenopausal women. The $C Y P 3 A 4$ and $C Y P 3 A 5$ mRNA expression level was higher in tumor size, tumor $<2 \mathrm{~cm}$ showed a higher expression of $C Y P 3 A 4$ and $C Y P 3 A 5$ than tumors of $>2 \mathrm{~cm}$. The level of CYP3A4 mRNA expression was found to be higher in high grade group (grade III) compared to intermediate grade (grade II), Whereas $C Y P 3 A 5$ showed high expression in intermediate grade group (Grade II). The CYP3A4 (87\%, 14 of 16) and CYP3A5 (88\%, 18 of 20) expression was higher in Ki-67 expressed tumors.

\begin{tabular}{|l|l|l|}
\hline $\begin{array}{l}\text { Clinical } \\
\text { characteristics }\end{array}$ & $\begin{array}{l}\text { CYP3A4 } \\
\text { altered } \\
\text { expression } \\
(\mathbf{n = 1 6 )}\end{array}$ & $\begin{array}{l}\text { CYP3A5 } \\
\text { altered expression } \\
(\mathbf{n}=20)\end{array}$ \\
\hline Menopausal Status & $10(62 \%)$ & $12(60 \%)$ \\
\hline Premenopausal & $6(38 \%)$ & $8(40 \%)$ \\
\hline Postmenopausal & &
\end{tabular}

\begin{tabular}{|c|c|c|}
\hline \multicolumn{3}{|l|}{ Tumor Size } \\
\hline Above-2 & $10(62 \%)$ & $16(80 \%)$ \\
\hline Below-2 & $6(38 \%)$ & $4(20 \%)$ \\
\hline \multicolumn{3}{|l|}{ Tumor Grade } \\
\hline Grade III & $6(38 \%)$ & $16(80 \%)$ \\
\hline Grade II & $10(62 \%)$ & $4(20 \%)$ \\
\hline \multicolumn{3}{|l|}{ Lymph Nodes } \\
\hline No Nodes & $10(62 \%)$ & $12(60 \%)$ \\
\hline $1-5$ & $4(26 \%)$ & $6(30 \%)$ \\
\hline Above 5 & $2(12 \%)$ & $2(10 \%)$ \\
\hline \multicolumn{3}{|l|}{ Hormonal Status } \\
\hline ER/PR Positive & $2(13 \%)$ & $10(50 \%)$ \\
\hline ER/PR Negative & $14(87 \%)$ & $10(50 \%)$ \\
\hline Her-2 Positive & $4(25 \%)$ & $8(40 \%)$ \\
\hline Her-2 Negative & $12(75 \%)$ & $12(60 \%)$ \\
\hline Ki-67 Positive & $14(87 \%)$ & $14(88 \%)$ \\
\hline Ki-67 Negative & $2(13 \%)$ & $6(12 \%)$ \\
\hline
\end{tabular}

Table 4: Correlation of the CYP3A4 and CYP3A5 mRNA levels with breast cancer clinical data.

\section{Discussion}

Enzymes of the cytochrome P450 (CYP) subfamily 3A comprise the largest portion of the liver and small intestinal CYP protein and they are involved in the metabolism of $45 \%$ to $60 \%$ of all currently used drugs. In addition to drugs, $C Y P 3 A$ isozymes metabolize a variety of other compounds including steroid hormones, toxins and carcinogens $C Y P 3 A 4$ and $C Y P 3 A 5$ plays an important role in cell regulation via its involvement in the metabolism of a wide variety of endogenous metabolites active in cellular signaling [6]. In the present study we defined the gene expression of $C Y P 3 A 4$ and $C Y P 3 A 5$ in south Indian women with breast cancer. There was no statistical difference between CYP3A4 and CYP3A5 expression and clinical and pathological features.

The results obtained in the present study, showed that $C Y P 3 A 5$ gene expression was not significantly associated with breast cancer $(\mathrm{p}=0.14)$. Iscan [5], reported that $C Y P 3 A 5$ mRNAs were expressed neither in tumors nor in control tissue. CYP3A5 is highly expressed in normal prostate cells but absent in prostate cancer. Significant differences in CYP3A4 mRNA expression were observed between tumor tissue and the corresponding normal tissue $(\mathrm{p}<0.003)$. Hence, we determined that $C Y P 3 A 4$ expression has a potential role as a breast cancer prognosis marker. In other work, $C Y P 3 A 4$ gene expression was observed, although in low levels, in breast cancer. The authors suggest that CYP3A4 expression is predictive value for any estimation of response to anticancer drugs metabolically inactivated by this cytochrome [7]. Yasuo Miyoshi [8-10], found that high CYP3A4 mRNA expression is significantly associated with a low response rate to DOC treatment in breast cancer patients [11-13]. 


\section{Conclusion}

$C Y P 3 A 4$ expression has a potential role as a breast cancer prognosis marker. We conclude that increased expression levels of the examined CYP3A4 may promote breast cancer progression and also may associate with resistance to drug treatment by inactivation of anticancer drugs. Moreover, one potential therapeutic approach may be to block CYP3A4 function. However, there were still some limitations that should be mentioned. The number of samples was limited $[14,15]$. There was lack of multi-center samples to validate our findings in particular. Second, the precise role of two genes in carcinogenesis remained unclear. Further validation with a larger number of samples was warranted to strengthen our results.

\section{References}

1. Jemal A, Siegel R, Ward E, Murray T, Xu J, et al. (2006) Cancer statistics, 2006. CA Cancer J Clin 56: 106-130.

2. Gonzalez FJ (2005) Role of cytochromes P450 in chemical toxicity and oxidative stress: Studies with CYP2E1. Mutat Res 569: 101-110.

3. Dvorak Z, Pavek P (2008) The role of redox-sensitive transcription factors NF-kB and AP-1 in the modulation of the Cyp1A1 gene by mercury, lead, and copper. Free Radic Biol Med 45: 939.

4. Constable S, Johnson MR, Pirmohamed M (2006) Pharmacogenetics in clinical practice: Considerations for testing. Expert Rev Mol Diagn 6: 193-205.

5. Iscan M, Klaavuniemi $\mathrm{T}$, Coban $\mathrm{T}$, Kapucuoglu $\mathrm{N}$, Pelkonen $\mathrm{O}$, et al. (2001) The expression of cytochrome P450 enzymes in human breast tumours and normal breast tissue. Breast Cancer Res Treat 70: 47-54.

6. Hassan BA, Yusoff ZB (2011) Genetic polymorphisms in the three Malaysian races effect granisetron clinical antiemetic actions in breast cancer patients receiving chemotherapy. Asian Pac J Cancer Prev 12: 185-191.
7. Vaclavikova R, Hubackova M, Stribrna-Sarmanova J, Kodet R, Mrhalova $\mathrm{M}$, et al. (2007) RNA expression of cytochrome P450 in breast cancer patients. Anticancer Res 27: 4443-4450.

8. Miyoshi Y, Ando A, Takamura Y, Taguchi T, Tamaki Y, et al. (2002) Prediction of response to docetaxel by CYP3A4 mRNA expression in breast cancer tissues. Int J Cancer 97: 129-132.

9. Yang M, Wang M, Gui H, Mao C (2018) Influence of CYP3A and ABCB1 single nucleotide polymorphisms on the pharmacokinetics/ pharmacodynamics of tacrolimus in pediatric patients. Curr Drug Metab.

10. Goicoechea I, Rezola R, Arestin M, Caffarel M, Cortazar AR, et al. (2017) Spatial intratumoural heterogeneity in the expression of GIT1 is associated with poor prognostic outcome in oestrogen receptor positive breast cancer patients with synchronous lymph node metastases. Version 2. F1000Res 6: 1606.

11. Suehiro S, Matsuda M, Hirata T, Taniyama D, Kuraoka K, et al. (2017) Primary cardiac rhabdomyosarcoma developed after receiving radiotherapy for left breast cancer 18 years prior. J Cardiol Cases 15: 181-183.

12. Baker GJ, Girvan HM, Matthews S, McLean KJ, Golovanova M, et al. (2017) Expression, purification, and biochemical characterization of the flavocytochrome P450 CYP505A30 from Myceliophthora thermophila. ACS Omega 2: 4705-4724.

13. Wang Y, Li X, Gao Y, Li Z, Yu L, et al. (2016) Genetic polymorphisms of CYP3A4 among Chinese patients with steroid-induced osteonecrosis of the femoral head. Medicine (Baltimore) 95: e5332.

14. Zhuravlyova LV, Shekhovtsova YO (2016) Role of c-reactive protein and tumor necrosis factor- $\alpha$ in immunoregulation system in patients with concomitant course of chronic pancreatitis and type 2 diabetes mellitus. Eksp Klin Gastroenterol 6: 33-36.

15. Minchenko OH, Tsymbal DO, Minchenko DO, Kubaychuk OO (2016) Hypoxic regulation of MYBL1, MEST, TCF3, TCF8, GTF2B, GTF2F2 and SNAI2 genes expression in U87 glioma cells upon IRE1 inhibition. Ukr Biochem J 88: 52-62. 